\title{
DINAMIKA PSIKOLOGIS PADA PELAKU PERCOBAAN BUNUH DIRI
}

\author{
Luluk Mukarromah \\ Fathul Lubabin Nuqul \\ Fakultas Psikologi \\ Universitas Islam Negeri (UIN) Maulana Malik Ibrahim Malang
}

\begin{abstract}
Abstrak - Percobaan bunuh diri merupakan fenomena yang sering terjadi di berbagai belahan dunia. Percobaan bunuh diri berhubungan erat dengan aspek psikologis dan pengambilan keputusan, ketika seseorang dihadapkan pada suatu permasalahan maka seseorang memiliki dua pilihan yaitu menyelesaikan permasalahan tersebut dengan cara yang positif atau dengan cara yang negatif yaitu, bunuh diri. Subjek dalam penelitian ini adalah dua orang perempuan usia 22 tahun, yang pernah melakukan usaha bunuh diri, namun masih selamat dan juga beberapa informan yang terkait dengan subjek. Teknik pengumpulan data yang digunakan yaitu wawancara mendalam, observasi dan penggunaan alat ukur psikologi yaitu BDI (Beck Depression Inventory), SCL 90, Grafis dan WARTEG. Hasil penelitian menunjukkan bahwasannya percobaan bunuh diri dilakukan karena adanya rasa kehilangan dan sebagai sarana untuk mengekspresikan emosi-emosi negatif yang dirasakan, hal ini disebabkan oleh depresi yang muncul tidak dapat direduksi oleh ego, ini sejalan dengan teori Freud mengenai bunuh diri yaitu adanya pembalikan agresi pada diri sendiri akibat adanya rasa kehilangan objek cinta. Sejalan dengan teori Beck mengenai depresi, pada penelitian ini juga ditemukan adanya depresi sebelum dan pasca percobaan bunuh diri. Pada penelitian ini juga ditemukan bahwasannya mereka yang melakukan percobaan bunuh diri cenderung tidak berpikir sistematis, ini bertentangan dengan teori perkembangan Piaget yang menyatakan adanya kematangan logika berpikir dan cenderung berpikir sistematis sebelum mengambil tindakan lebih jauh. Hal ini dipengaruhi oleh depresi yang timbul sebelum percobaan bunuh diri berlangsung. Depresi juga didukung karena adanya tekanan dari lingkungan sosial dan subjek tidak mampu menyesuaikan dirinya, didukung dengan adanya faktor internal yaitu pandangan negatif pada diri dan masa depan, maka timbul rasa frustrasi yang diwujudkan dengan percobaan bunuh diri, hal ini sesuai dengan bunuh diri egoistik dan anomi.
\end{abstract}

Kata Kunci: Percobaan Bunuh Diri, Pengambilan Keputusan

PSIKOISLAMIKA. Jurnal Psikologi Islam (JPI) copyright @ 2014 Laboratorium Penelitian, Kajian Psikologi Islam dan Penerbitan. Volume 11. Nomor 2, Tahun 2014

\section{PENDAHULUAN}

Bunuh diri merupakan fenomena yang menarik untuk dikaji, hal ini dikarenakan bunuh diri merupakan fenomena yang sampai saat ini belum bisa ditentukan akar permasalahannya secara spesifik. Dari beberapa penelitian ditemukan bahwasannya bunuh diri disebabkan oleh kombinasi faktor dan motivasi pelaku yang saling berkaitan satu sama lain, baik faktor dan motivasi instrinsik ataupun ekstrinsik. Faktor dan motivasi instrinsik berarti penyebab ataupun dorongan dari dalam diri pelaku percobaan bunuh diri, misalnya keadaan psikologis yang sedang tidak seimbang atau ingin lari dari rasa sakit yang dirasakan, sedangkan faktor dan motivasi ekstrinsik yaitu penyebab ataupun dorongan dari luar yang berkaitan dengan pelaku percobaan bunuh diri, misalnya keadaan ekonomi yang sulit, permasalahan yang dihadapi atau bunuh diri dikarenakan berharap bahwa mereka akan dirindukan atau dikenang setelah kematian mereka. 
Perlu adanya penelitian mendalam mengenai bunuh diri, untuk menemukan kecenderungankecenderungan seseorang melakukan percobaan bunuh diri. Penelitian-penelitian terdahulu umumnya hanya membahas mengenai keterkaitan satu faktor atau beberapa faktor dengan perilaku bunuh diri, belum ada penelitian yang membahas mengenai gambaran psikologi sampai seseorang akhirnya memutuskan melakukan bunuh diri. Untuk itu peneliti perlu melakukan penelitian dengan judul, "Dinamika Psikologis Pada Pelaku Percobaan Bunuh Diri (Tentament Suicide)." Diharapkan dari penelitian ini akan ditemukan gambaran psikologis meliputi faktor-faktor, motivasi dan pengambilan keputusan dari pelaku percobaan bunuh diri, yang nantinya akan bermanfaat sebagai upaya penanggulangan bunuh diri dan sebagai tambahan referensi mengenai percobaan bunuh diri.

\section{KERANGKA KERJA TEORITIK}

Ada beberapa teori yang menjelaskan dinamika bunuh diri antara lain psikoanalisis dan paradigma kognitif. Dalam psikoanalisa, Freud berpendapat bahwasannya tujuan dari kehidupan adalah kematian dari sinilah kemudian muncul dorongan agresif yang tujuannya untuk mempertahankan ego atau ke-akuan dengan cara menyalurkan insting kematian yang sifatnya merusak ke objek luar dan mengubahnya menjadi tindakan yang bisa diterima oleh lingkungan, hal ini dimaksudkan untuk menyalurkan energi dari insting kematian, namun kegagalan ego untuk menyalurkan insting kematian keluar dirinya menyebabkan agresi berbalik kedalam dirinya sendiri dan apabila cukup kuat orang tersebut akan bunuh diri.

Hal ini menurut Freud merupakan fase depresi, dalam tulisannya Mourning and Melancholia (Freud, 1917/1950. dalam Davidson, 2006) dikatakan bahwa potensi depresi diciptakan pada awal kanak-kanak. dalam periode oral, kebutuhan seorang anak dapat kurang dipenuhi atau dipenuhi secara berlebihan sehingga menyebabkan seseorang terfiksasi pada tahap ini, dan tergantung pada pemenuhan kebutuhan instingtual yang menjadi ciri tahap ini. Dengan terbawanya kondisi tersebut dalam tahap pematangan psikoseksual, fiksasi pada tahap oral tersebut, orang yang bersangkutan dapat memiliki kecenderungan untuk sangat tergantung pada orang lain untuk mempertahankan harga dirinya. Sedangkan akar permasalahan dari depresi sendiri yaitu karena kehilangan cinta pada oedipus complex yang membuat orang marah kepada diri sendiri karena dia kehilangan cinta dari orang tua, dari teman bahkan dari negaranya (Alwisol, 2009).

Berbeda dengan Freud yang menganggap depresi berasal dari kehidupan masa lalunya. Beck (1985) menganggap bahwa depresi disebabkan oleh cara berpikir yang salah terhadap dirinya, sehingga ia cenderung menyalahkan dirinya sendiri (Lubis, 2009) ini disebabkan adanya distorsi kognitif yang dialami terhadap diri, dunia dan masa depannya, hal inilah yang kemudian menimbulkan model kognitif depresi seperti yang dikemukakan oleh Beck. Model ini terdiri dari tiga konsep khusus yaitu cognitive triad, proses informasi yang salah dan skema-skema (Lubis, 2009).

Dalam pandangan kognitif, selain adanya kesalahan cara berfikir juga menarik untuk mentelaah cara pengambilan keputusan tindakan percobaan bunuh diri. Pembuatan keputusan atau decision making ialah proses memilih atau menentukan berbagai kemungkinan di antara situasi-situasi yang tidak pasti (Suharnan, 2005). Pembuatan keputusan terjadi di dalam situasi-situasi yang meminta seseorang harus membuat prediksi ke depan, memilih salah satu diantara dua pilihan atau lebih, atau membuat estimasi (perkiraan) mengenai frekuensi kejadian berdasarkan buktibukti yang terbatas. Namun tidak semua keputusan diambil dengan menggunakan pertimbangan yang sistematis seperti pada teori keputusan klasik di atas, melainkan dengan menggunakan pendekatan Heuristik. Heuristik menurut Suharnan (2005) adalah cara menentukan sesuatu melalui hokum kedekatan, kemiripan, kecenderungan atau keadaan yang diperkirakan paling mendekati kenyataan.

\section{METODE}

Penelitian menggunakan pendekatan kualitatif dengan metode studi kasus. Subjek dalam penelitian ini terdiri dari dua orang perempuan berusia 22 tahun dengan kriteria pernah melakukan percobaan bunuh. Guna melengkapi data peneliti melibatkan tiga orang informan, satu orang informan untuk subjek pertama yaitu teman dekat subjek, dan dua orang informan untuk subjek kedua yaitu teman dekat subjek dan teman dekat orang tua subjek. Subjek penelitian dipilih berdasarkan teknik purposive sampling, metode ini dipilih karena pada awal penelitian subjek sudah menentukan orang yang akan dijadikan sebagai subjek penelitian karena dianggap sebagai orang yang bisa memberikan informasi yang sesuai dengan tema penelitian.

Metode pengumpulan data yang digunakan yaitu 
wawancara, observasi, dan alat ukur piskologi. Alat ukur yang digunakan dalam penelitian ini yaitu $\mathrm{SCL}$ 90 , yang berfungsi untuk melihat kecenderungan klinis, BDI (Beck Depression Inventory), untuk melihat ada tidaknya gangguan depresi, kemudian tes Grafis dan tes WARTEG yang berguna untuk melihat kepribadian subjek. Teknik analisis yang digunakan yaitu teknik analisis domain, menurut Bungin (2003) analisis domain digunakan untuk menganalisis gambaran objek penelitian secara umum atau ditingkat permukaan, namun relatif utuh tentang objek penelitian tersebut. Sedangkan teknik pemeriksaan keabsahan data yang digunakan pada penelitian ini adalah teknik triangulasi, menurut Patton (dalam Moleong, 2007) teknik triangulasi yaitu membandingkan dan mengecek balik derajat kepercayaan suatu informasi yang diperoleh melalui waktu dan alat yang berbeda dalam penelitian kualitatif.

\section{HASIL DAN PEMBAHASAN}

Berdasarkan hasil wawancara dan asesmen psikologis menunjukkan bahwa pelaku percobaan bunuh diri melakukan tindakannya disebabkan adanya rasa kehilangan, selain itu juga dilakukan sebagai sarana untuk mengungkapkan emosi-emosi negatif pada orang lain yang dirasakannya. Hal ini terjadi karena ego yang lemah, sehingga pelaku cenderung tidak bisa membentengi diri dan gagal membelokkan agresi pada objek di luar dirinya. Ego ini dibentuk oleh keluarga dan lingkungan sosialnya.

Percobaan bunuh diri dianggap oleh pelaku sebagai jalan keluar dari masalah yang dihadapi, percobaan bunuh diri juga dianggap sebagai suatu cara untuk mengubah realitas yang terjadi, seperti kehilangan cinta dan kondisi keluarga yang menimbulkan emosi-emosi negatif.

Selain itu juga ditemukan bahwa pengambilan keputusan dalam bunuh diri cenderung menggunakan pendekatan heuristik, yang bersifat tidak sistematis dan cepat. Keputusan ini juga dipengaruhi oleh depresi yang dialami. Depresi pada pelaku ditandai oleh tiga hal yang kemudian membentuk skema kongnitif yang bersifat negatif. Tiga hal tersebut meliputi pandangan negatif pada diri dan masa depan, adanya pengulangan ide bunuh diri dan pikiran ambivalen, dan distorsi kognitif yang membuat seseorang tidak bisa berpikir mengenai solusi lain yang lebih baik.

Percobaan bunuh diri merupakan fenomena yang sering terjadi di seluruh belahan dunia. Dari hasil penelitian dapat diketahui bahwasannya, pelaku percobaan bunuh diri memiliki beberapa kesamaan yaitu, mereka sama-sama datang dari keluarga yang tidak harmonis, meskipun hal ini tidak berpengaruhi secara langsung pada kedua-duannya, namun ini menjadikan subjek cukup emosional ketika dihadapkan pada suatu permasalahan. Menurut Lubis (2009) anak yang ditolak oleh orang tuanya akan menjadi malu dan bingung, karena selalu diombang-ambingkan perasaan cinta kasih dan kekecewaan atau kebencian terhadap orang tuanya, sehingga anak-anak akan mengalami kekalutan batin. Timbullah rasa tidak aman secara emosional (emotional insecurity) dan akan mengakibatkan konflik batin yang serius, trauma yang ditimbulkan dari penolakan orang tua akan berpengaruh terhadap pengendalian emosi anak kelak ketika dewasa, sehingga ketika dihadapkan pada permasalahan atau tekanan hidup anak cenderung cepat frustasi bahkan sebagai puncaknya akan muncul kecenderungan untuk bunuh diri.

Selain itu perlakuan kasar yang diterima subjek membuatnya mencari figur pelindung yang tidak ditemukan dalam keluarganya. figur ini ditemukan subjek pada tunangannya yang merupakan orang yang dicintainya, sehingga ketika subjek putus dengan tunangannya ia merasa sedih dan kehilangan figur pelindung sekaligus orang yang dicintainya tersebut. Freud (dalam Husain, 2005) mengatakan bahwa kehilangan cinta, dapat menimbulkan dua hal yaitu, apabila perasaan yang ditarik oleh ego adalah perasaan cinta dan penghormatan maka cinta tersebut akan kembali pada ego, sehingga dia mencintai dirinya sendiri hal ini merupakan poros dari narsisme, namun kehilangan cinta seringkali menimbulkan perasaan benci dan permusuhan yang gagal mengaktualisasikan dirinya, perasaan ingin menghukum objek cinta yang telah hilang kemudian dibalikkan pada ego sendiri ini merupakan poros sadisme, dan juga poros dari masokhisme. Ini dikarenakan menyiksa diri sendiri adalah refleksi dari objek cinta yang kejam.

Hal ini oleh Freud dijelaskan sebagai fase depresi dalam Mourning and Melancholia. (Freud, 1917/1950. dalam Davidson, 2006) untuk menghilangkan frustrasi atau tegangan akibat kehilangan objek cinta, ego menggunakan mekanisme pertahanan berupa reaksi agresi (aggressive reaction) yaitu, menggunakan dorongan agresi untuk menyerang objek yang menimbulkan frustrasi, (Alwisol, 2009) namun kegagalan ego karena tidak dapat menemukan objek cinta yang telah hilang dan tidak menemukan 
objek penganti, menyebabkan agresi dibalikkan ke dirinya sendiri. Ini dikarenakan adanya ego yang lemah, pembentukan ego sendiri dipengaruhi oleh lingkungan keluarga dan lingkungan sosialnya.

Sedangkan temuan lain dalam penelitian ini menemukan adanya permasalahan dengan keluarga mulai dari konflik dengan ibunya, ayah subjek yang meninggal dan konflik dengan kakaknya menjadi pemicu distres subjek selama bertahun-tahun sehingga timbul emosi-emosi negatif seperti stres, marah dan malu. Dari sini subjek berusaha mengungkapkan emosi negatif tersebut dengan melakukan percobaan bunuh diri. Menurut Kartono (2000) salah satu karakteristik orang yang cenderung melakukan percobaan bunuh diri, yaitu selalu dihantui atau dikejar-kejar rasa cemas, takut, tegang, depresi, marah, dendam, dosa atau bersalah.

Tentu hal ini bukan satu-satunya faktor yang menyebabkan subjek melakukan percobaan bunuh diri, mereka juga memandang negatif pada diri dan masa depannya, subjek memandang negatif pada dirinya karena pelecehan seksual yang pernah dialaminya dan keadaan diri yang sudah tidak perawan lagi, ini membuat subjek takut akan masa depannya dan takut tidak akan ada yang mau menerimanya lagi. $\mathrm{Hal}$ ini sesuai dengan teori depresi yaitu kongnitif triad yang diusulkan oleh Aaron Beck (dalam Lubis, 2009) yaitu adanya pengaktifan tiga serangkai pola kognitif yang membuat individu memandang dirinya, pengalamannya dan masa depannya secara idiosinkritik. Hasil penelitian juga menyebutkan adanya simtom psikologis yaitu depresi dan simtom fisik yaitu keadaan subjek yang sedang sakit.

Dari hasil penelitian juga ditemukan adanya kepribadian yang cenderung dependen pada orang lain, sehingga ketika dihadapkan pada permasalahan subjek cenderung kurang bisa mengatasi masalah tersebut. selain itu subjek juga cenderung melankolis. Menurut Nietzel \& Harris (1990) (dalam Davidson dkk, 2006) beberapa orang yang depresi memiliki ketergantungan yang tinggi dan cenderung menjadi depresi setelah ditolak.

Faktor-faktor di atas tidak berdiri secara sendiri melainkan saling berkaitan satu sama lain, dari faktor-faktor tersebut memunculkan adanya motif percobaan bunuh diri. Hasil penelitian menunjukkan adanya motivasi interpersonal, yaitu sebagai bentuk usaha untuk mengembalikan objek cinta yang telah hilang, disisi lain percobaan bunuh diri dilakukan sebagai sarana penyaluran emosi-emosi negatif yang dirasakannya. Menurut Kartono (2000) motivasi interpersonal dalam kasus bunuh diri terjadi apabila pribadi yang melakukan tindakan bunuh diri tersebut lewat perbuatannya berusaha untuk mempengaruhi terjadinya sikap pada orang lain atau mengharapkan adanya perubahan tingkah laku pada orang lain. Perbuatan bunuh diri juga digunakan sebagai ekspresi dari kemarahan, penolakan dan pemaksaan kesediaan untuk mengubah prilaku pada orang lain.

Selain itu juga ditemukan motif lain yaitu, percobaan bunuh diri dilakukan sebagai solusi dari permasalahan yang dihadapi, hal ini sesuai dengan pendapat Shneidman (dalam Davidson dkk, 2006) yang menganggap bunuh diri sebagai upaya sadar untuk mencari solusi suatu masalah yang menyebabkan penderitaan mendalam.

Dari faktor dan motif tersebut kẹmudian muncul ide untuk mati atau bunuh diri, yaitu kurang dari seminggu sampai satu bulan. Sebelum percobaan bunuh diri pikiran subjek dipenuhi dengan ide ini dan motif atau harapan yang ingin dicapai dari percobaan bunuh diri, selain itu subjek juga berpikir mengenai pengalaman-pengalaman negatif seperti pelecehan seksual yang dialami dan kedaan yang sudah tidak perawan, hal ini menimbulkan ketakutan akan masa depan subjek. Ini sesuai dengan teori Beck mengenai dichotomous thinking, $\mathrm{Hal}$ ini dimanifestasikan dalam kecenderungan untuk menempatkan semua pengalaman kedalam satu atau dua kategori yang berlawanan (Lubis 2009). Namun subjek masih memiliki pertimbangan seperti tidak ingin merasa sakit ketika melakukan percobaan bunuh diri sehingga memilih alat dan dengan cara yang tidak mendatangkan kematian secara langsung, hal ini dipengaruhi oleh motif percobaaan bunuh diri yang bertujuan untuk memaksa orang lain untuk kembali padanya dan sebagai sarana penyaluran emosi negatif.

Percobaan bunuh diri dilakukan dengan cara menyayat-nyayat tangan dengan sayatan yang tidak dalam dan dengan menggunakan obat. Pada saat percobaan bunuh diri, subjek sadar akan resiko dari tindakannya namun ia tidak bisa berpikir solusi lain yang lebih baik selain bunuh diri. Hal ini dikarenakan adanya pengerutan kongnitif atau distorsi kognitif yang mengakibatkan adanya deficit problem solving. Pengambilan keputusan diwarnai pikiran-pikiran yang cenderung mengandung tema depresif dan memperlihatkan tema kemunduran (personal deficiency).

Dilihat dari usia subjek yang berada pada tahap dewasa awal, menurut Piaget (dalam Boeree, 2009) pada umumnya orang pada tahap 
dewasa awal sudah mencapai tahap operasional formal, dimana pada tahap ini seseorang sudah mencapai kematangan dalam prinsip-prinsip logika dan dapat menggunakannya untuk menyelesaikan permasalahan yang bersifat abstrak, pada tahap ini juga orang mampu mempertimbangkan kemungkinankemungkinan ketika menghadapi permasalahan sebelum mengambil tindakan yang lebih jauh. Namun dari hasil penelitian ditemukan bahwasanya pelaku percobaan bunuh diri, cenderung fokus pada permasalahanya dan tidak berpikir mengenai solusi atau pertimbangan lain, sebelum melakukan percobaan bunuh diri. Hal ini bisa dikarenakan adanya depresi yang mengakibatkan penurunan fungsi kognitif.

Pasca percobaan bunuh diri subjek mengalami stres dan depresi, yang membuat subjek cenderung menutup diri. Dukungan dari lingkungan sosial sangat berperan dalam membantu seseorang keluar dari stres dan depresi yang dirasakannya, sehingga kurang adanya dukungan dari lingkungan menyebabkan subjek melakukan percobaan bunuh diri berulang kali. Jika dikaitkan dengan teori bunuh diri menurut Emile Durkheim (dalam Upe, 2010) percobaan bunuh diri dilakukan karena kurangnya disiplin atau integrasi sosial, dilihat dari hasil penelitian percobaan bunuh diri yang dilakukan tergolong bunuh diri egoistik dan anomi. Percobaan bunuh diri dilakukan karena kurangnya integrasi sosial dalam hal ini yaitu keluarga sehingga subjek tidak merasa terikat dan menganggap kepentingannya lebih besar dari kepentingan sosialnya. Ketika subjek merasa apa yang diharapkannya tidak sesuai dengan harapannya ia mudah menjadi bimbang dan bahkan tidak memiliki tujuan hidup lagi, hal inilah kemudian yang membuat subjek memutuskan melakukan percobaan bunuh diri. Disisi lain adanya konflik dengan lingkungan sosial, menunjukkan adanya ketidakmampuan dalam menjalankan role expectation, yaitu peran yang diharapkan masyarakat, sehingga subjek merasa frustrasi dan memutuskan untuk melakukan percobaan bunuh diri (Siahaan, 1986).

Dilihat dari karakteristik pengambilan keputusan secara khusus, umumnya ketika dihadapkan dengan permasalahan subjek cenderung tidak menggunakan pemikiran yang matang dan sistematik melainkan menggunakan pemikiran nonsistematik yang dikenal dengan pendekatan Heuristik. Hal ini sesuai dengan hasil penelitian yang dilakukan oleh Jolliant dkk. (2005) (dalam Halgin \& Whitbourne, 2011) adanya penurunan kemampuan dalam mengambil keputusan pada pelaku percobaan bunuh diri yang cenderung mengambil keputusan yang tidak bijaksana. Pendekatan heuristik menurut Suharnan (2005) adalah cara menentukan sesuatu melalui hukum kedekatan, kemiripan, kecenderungan atau keadaan yang di perkirakan paling mendekati kenyataan. Pada kasus percobaan bunuh diri ditemukan bahwasannya tidak adanya perencanaan ketika seseorang memutuskan untuk melakukan percobaan bunuh diri melainkan hanya diputuskan sesaat sebelum percobaan bunuh diri berlangsung, hal ini sebagai respon atas keadaan yang menimbulkan frustrasi, pada keadaan ini seseorang cenderung berusaha mereduksi tegangan dengan membayangkan alternatif-alternatif yang normal diluar fakta. Pada subjek penelitian ditemukan bahwasannya ia membayangkan kekasihnya akan kembali kalau dia melakukan percobaan bunuh diri, atau prilaku orang disekitarnya akan berubah ketika ia melakukan percobaan bunuh diri.

Dalam pendekatan heuristis hal ini dikenal dengan heuristis simulasi dengan penalaran kontrafaktual (Taylor dkk, 2009). Saat seseorang memunculkan pikiran berandai-andai ini, orang biasanya hanya fokus pada kejadian atau tindakan tertentu, dalam hal ini subjek hanya fokus pada kejadian kehilangan dan rasa marah sedangkan tindakan yang dibayangkan yaitu percobaan bunuh diri. Ketika dihadapkan pada persoalan yang serius seperti menyangkut hidup dan mati, umumnya orang akan berpikir secara sistematik dengan berbagai pertimbangan, namun pada pelaku percobaan bunuh diri cenderung sebaliknya. Ini bisa dipengaruhi oleh mental set yang terbentuk berdasarkan pengalaman dan cenderung tidak disadari, menurut Aarts \& Dijksterhuis (2003) pada dasarnya, karena bertahun-tahun kita merespon emosional, kognitif dan perilaku terhadap berbagai situasi menjadi otomatis (Taylor dkk, 2009).

Hasil penelitian menunjukkan bahwasannya mereka hanya berpikir mengenai pikiran-pikiran yang cenderung mengandung tema depresif dan memperlihatkan tema kemunduran (personal deficiency). Pertama yaitu mereka cenderung memandang diri dan masa depannya secara negatif hal ini disebut oleh Beck dengan pengaktifan kongnitif triad, Kedua mereka cenderung mengulang-ulang ide yang sama yaitu bunuh diri, dan ditambah adanya proses informasi yang salah dan cenderung untuk menempatkan semua pengalaman kedalam satu atau dua kategori yang berlawanan atau berpikir ambivalen, yaitu selain berpikir mengenai harapan dan tujuan bunuh diri ia juga berpikir mengenai 
pengalaman-pengalaman negatif yang pernah ia alami, jadi terdapat keinginan untuk mati atau hidup yang tidak jelas, hal ini sesuai dengan karakteristik yang diungkapkan oleh Kartono (2000). Ketiga, subjek juga mengalami penurunan fungsi Kongnitif atau distorsi kongnitif yang membuatnya tidak bisa melihat alternatif lain selain bunuh diri sebagai solusi dari permasalahan yang dihadapi. Hal ini kemudian membentuk suatu skema negatif berdasarkan tematema idiosinkratik di atas, hal inilah yang kemudian membuat seseorang mengambil keputusan untuk melakukan percobaan bunuh diri.

\section{KESIMPULAN}

Berdasarkan hasil dan pembahasan dapat disimpulkan bahwa percobaan bunuh diri dilakukan karena adanya emosi negatif karena emosi-emosi negatif yang dirasakannya. Hal ini terjadi karena

\section{DAFTAR PUSTAKA}

Al-Husain. S. 2005. Mengapa Harus Bunuh Diri. Jakarta : Qisthi Press.

Alwisol. 2009. Psikologi Kepribadian. Malang: UMM Press.

Boeree. C. G. 2009. Personality Theories. Sleman, Jogjakarta: Prismasophie.

Bungin. B. 2003. Analisis Data Penelitian Kualitatif: Pemahaman Filosofis Dan Metodologis Arah Penguasaan Model Aplikasi. Jakarta: PT Raja Grafindo Persada.

Davidson. G. C. \& Neale, J M. 2006. Psikologi Abnormal, Edisi ke- 9. Jakarta : PT Rajagrafindo Persada.

Halgin. R. P. \& Whitbourne. S K. 2011. Psikologi Abnormal. Jakarta: Salemba Humanika. ego yang lemah, gagal membelokkan agresi pada objek diluar dirinya. Ego ini dibentuk oleh keluarga dan lingkungan sosialnya, percobaan bunuh diri merupakan jalan keluar dari masalah yang dihadapi, percobaan bunuh diri juga dianggap sebagai suatu cara untuk mengubah realitas yang terjadi, Pengambilan keputusan dalam bunuh diri cenderung menggunakan pendekatan heuristis, yang bersifat tidak sistematis dan cepat, hal ini juga dipengaruhi oleh depresi yang dialami, depresi disini ditandai oleh tiga hal yang kemudian membentuk skema kongnitif yang bersifat negatif. Tiga hal ini meliputi pandangan negatif pada diri dan masa depan, adanya pengulangan ide bunuh diri dan pikiran ambivalen, dan distorsi kognitif yang membuat seseorang tidak bisa berpikir mengenai solusi lain yang lebih baik.

Kartono. K. 2000. Hygiene Mental. Bandung: Mandar Maju.

Lubis, N L. 2009. Depresi: Tinjauan Psikologis. Jakarta: Kencana.

Moleong, L. J. 2007. Metodologi Penelitian Kualitatif. Bandung: PT. Remaja Rosdakarya.

Siahaan, H.M. 1986. Pengantar ke Arah Sejarah dan Teori Sosiologi. Jakarat: Penerbit Erlangga.

Suharnan. 2005. Psikologi Kognitif. Surabaya: Srikandi.

Taylor, S E., Peplau, L A,. \& Sears, D O. 2009. Psikologi Sosial. Jakarta: Kencana Prenada Media Group.

Upe, A. 2010. Tradisi Aliran Dalam Sosiologi: Dari Filosofi Positivistic Ke Post Positivistik. Jakarta: PT Raja Grafindo Persada. 